\title{
Occurrence of Talavera aperta (Miller, 1971) (Araneae: Salticidae) in Poland
}

\author{
ROBERT ROZWAŁKA ${ }^{1}$, TOMASZ RUTKOWSKI ${ }^{2}$, PAWEŁ SIENKIEWICZ ${ }^{3}$ \\ and KATARZYNA RENN ${ }^{4}$
}
'Department of Zoology, Maria Curie-Sklodowska University, Akademicka 19, 20-033 Lublin, Poland; e-mail: arachnologia@wp.pl
${ }^{2}$ Natural History Collections, Faculty of Biology, Adam Mickiewicz University in Poznan, Umultowska 89, 61-614 Poznań, Poland; e-mail: pardosa@gazeta.pl ${ }^{3}$ Department of Entomology and Environmental Protection, Poznań University of Life Sciences, Dąbrowskiego 159, 60-594 Poznań, Poland; e-mail: carabus@up.poznan.pl
${ }^{4}$ Museum of the First Piasts at Lednica, Dziekanowice 32, 62-261 Lednogóra, Poland; e-mail: katarzyna.renn@interia.pl

Corresponding author: Robert Rozwałka, e-mail: arachnologia@wp.pl

(Received on 19 January 2015; Accepted on 8 December 2015)

\begin{abstract}
Talavera aperta is a rare member of the Salticidae (jumping spiders). Its presence in Poland has been questioned. This paper presents data on 20 new localities of this poorly known species and a map of its distribution in western and central Poland. Detailed drawings of the male body, male palps and the female epigynum are also provided. T. aperta was usually collected from dry, sunny habitats, mostly in June, although some specimens were recorded in other months. In winter, spiders of this species were found in shells of small snails (Cepaea spp., Helicella obvia).
\end{abstract}

Keywords: Talavera aperta, Salticidae, spiders, distribution, Poland, habitats, overwintering

\section{INTRODUCTION}

Talavera aperta (Miller, 1971) is a rare spider species with a Western Eurasian range (Logunov \& Kronestedt 2003; World Spider Catalog 2016). Its description by MilLer (1971), not very precise, resulted in several synonymizations with Talavera thorelli (Kulczyński, 1891) or Talavera monticola (Kulczyński, 1884) (comp. Logunov \& Kronested 2003; World Spider Catalog 2016).

There is a lot of confusion around the occurrence of T. aperta in Poland. STARĘGA (1984), on the basis of a male collected in the vicinity of Warsaw, recorded the species as new to Poland. Another site of occurrence of T. aperta, in eastern Poland, 

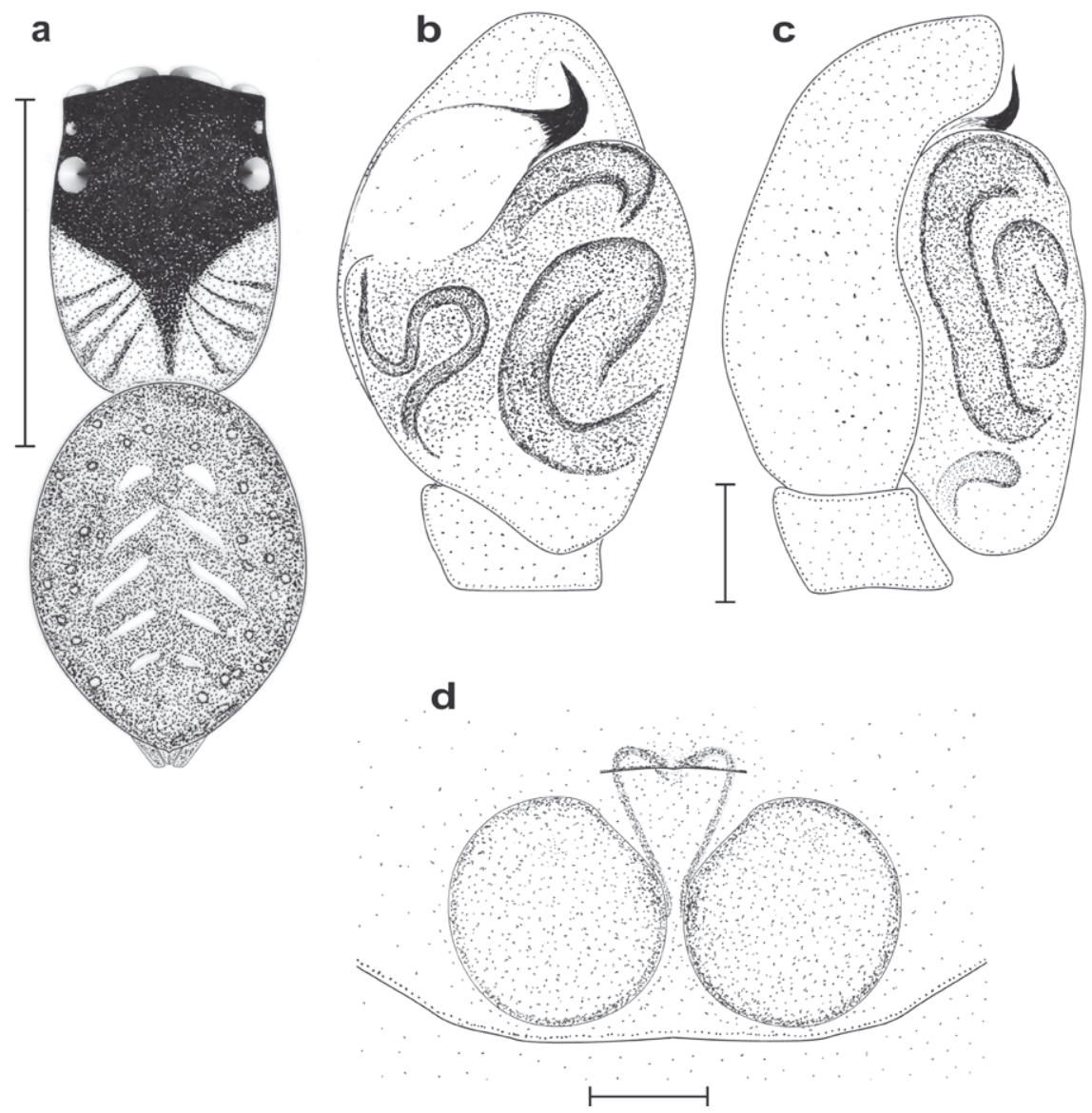

Fig. 1. Talavera aperta (MilLER): (a) male, overall view; (b) male palp, ventral view; (c) male palp, lateral view (specimen from Lednica Ethnographic Park); (d) female epigynum (specimen from Santok). Scale bar $=1 \mathrm{~mm}$ (a) or $0.1 \mathrm{~mm}$ (b-d) (drawings by R. Rozwałka)

was reported by RozwatKa (1995), but that record later proved to be false, due to misidentification of T. aequipes (O.P. Cambridge, 1871) (R. Rozwałka ver.). ŻABKA (1997) considered T. aperta as a junior synonym of T. monticola (Kulczyński), so he did not include it in the key to the Salticidae of Poland (ŻABKA 1997). PrósZYŃSKI \& STARĘGA (1997) and ŻABKA \& PRÓSZYŃSKI (1998) repeated the information about synonymization of $T$. aperta with $T$. monticola and deleted this species from the list of spiders of Poland. Nevertheless, BLICK et al. (2004), in accordance with STAREGA (1984), referred to T. aperta as a species occurring in Poland. The presence of $T$. aperta in Poland is also mentioned by Nentwig et al. (2016), STAudt (2016), and van Helsdingen (2016), mostly based on the checklist of spiders of Central Europe (BLICK 


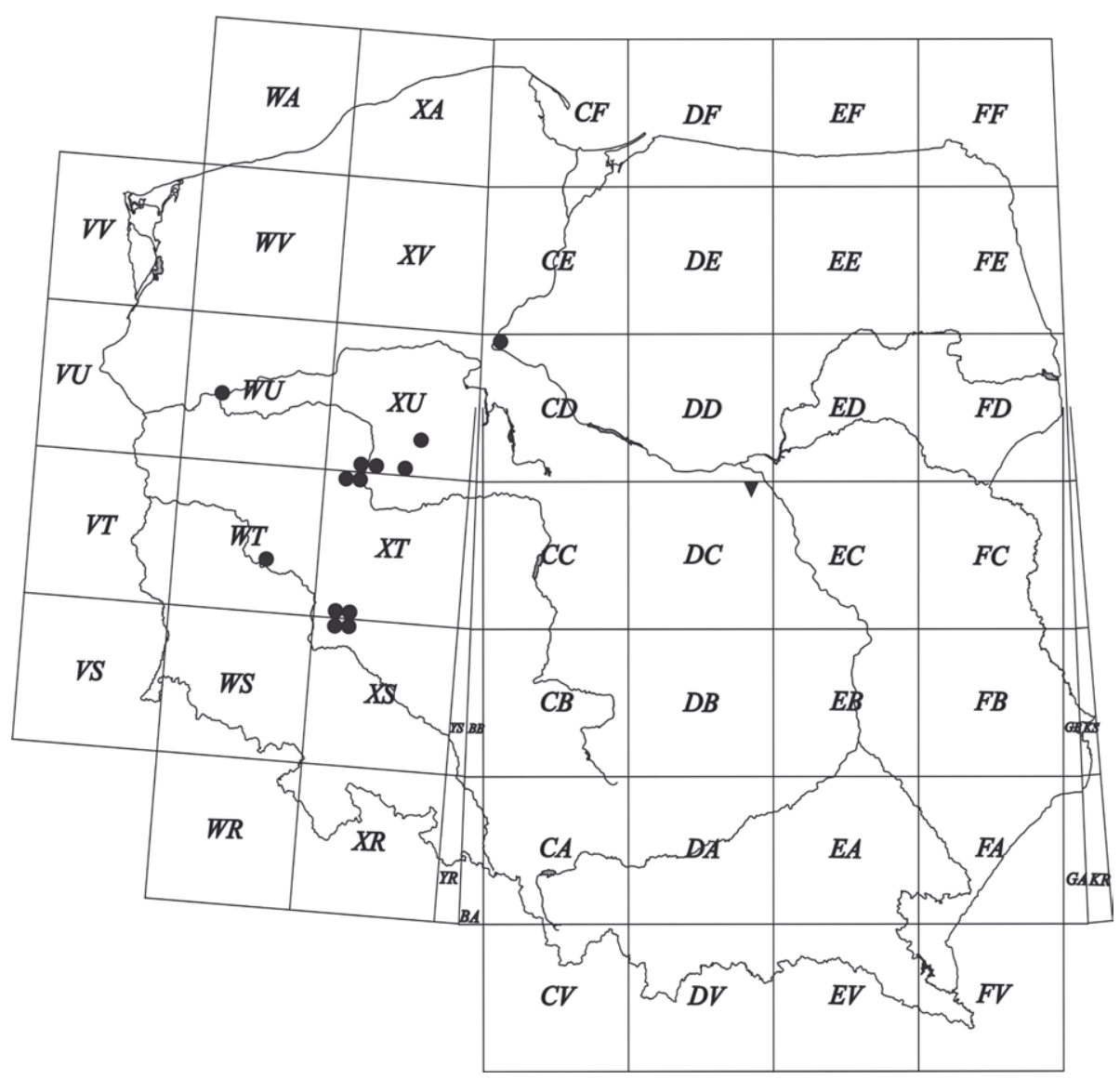

Fig. 2. Distribution of Talavera aperta in Poland: triangle $=$ literature data; circles $=$ new data

et al. 2004). In contrast, KUPRYJANOWICZ (2008), followed the earlier publications of PrószyŃSKi \& StaręGa (1997), ŻABKA (1997), and ŻABKA \& PrósZYŃSKi (1998), and did not include this species in the list of spiders of Poland.

In this paper, we present a series of new records of Talavera aperta in Poland (Fig. 2). All the records were made during faunistic studies (arachnological and entomological). Many specimens were found in Barber pitfall traps, routinely used to catch spiders, insects, and other terrestrial invertebrates.

\section{MATERIAL EXAMINED}

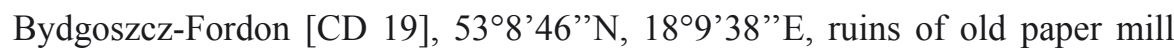
near railway line, in empty shells of Cepaea spp., leg. et det. T. Rutkowski: 24 Dec 
$2013-19,3$ juv.; in empty shells of Helicella obvia (Menke, 1828), syn. Xerolenta obvia (Menke, 1828) - 2 juv.

Lednica Etnographic Park [XU 62], 52³0'44'”N, 17²2’57’E, young orchard, pitfall traps, leg. K. Renn, det. R. Rozwałka: 6-28 June $2012-1 \sigma^{\top}$.

Lednica Etnographic Park [XU 62], 52 $31^{\prime} 01$ 'N, 17²2'47' E, xerothermic grassland near Lednica Lake, pitfall traps, leg. K. Renn, det. R. Rozwałka: 4 Aug - 9 Sep $2012-1$ juv.

Lisówki [XT 19], 52 $19^{\prime} 09^{\prime \prime} \mathrm{N}, 16^{\circ} 38^{\prime} 15^{\prime \prime} \mathrm{E}$, xerothermic grassland with hawthorn shrubs on south-facing slope, pitfall traps, leg. et det. T. Rutkowski: 4-14 June $2013-1 \hat{\jmath}, 1$ q ; $24 \mathrm{Apr}-8$ May $2014-1 \hat{\jmath}$.

Mosina near Poznań [XT 29], 52¹5'11 ’N, 1650’48”E, xerothermic grassland,

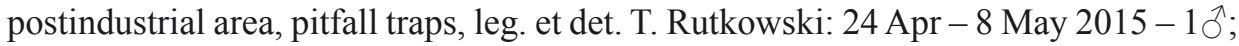
22 May -11 June $2015-2 \hat{\jmath}$.

Mosina near Poznań [XT 29], 52 $2^{\circ} 15^{\prime} 6^{\prime} \mathrm{N}, 16^{\circ} 50^{\prime} 51^{\prime \prime} \mathrm{E}$, xerothermic grassland, abandoned allotment gardens, pitfall traps, leg. et det. T. Rutkowski: 11-28 June $2015-1 \sigma^{\lambda}$.

Nieszkowice [XS 19], 51 $25^{\circ} 25^{\prime} \mathrm{N}, 16^{\circ} 43^{\prime} 01^{\prime \prime} \mathrm{E}$, complex of old gravel pits, sandy grassland, pitfall traps, leg. et det. T. Rutkowski: 31 May - 15 June $2013-1 \hat{\sigma}^{\prime}$.

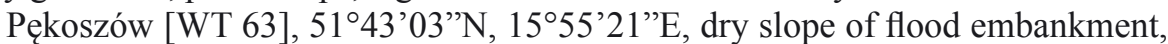

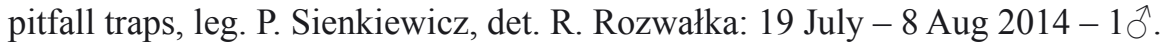

Pianówka [XU 05], 5252’4’’N, 16²9’33”'E, old railway line, under stones, leg. et det. T. Rutkowski: 7 May $2013-1 \hat{\jmath}$.

Pianówka [XU 05], 5252’42”N, 16²9’43”'E, thermophilous oak forest, pitfall traps, leg. G. Wojtaszyn, det. T. Rutkowski: 10-16 June $2013-2$ 우.

Pierusza [XS 29], 51 $24{ }^{\circ} 43^{\prime \prime} \mathrm{N}, 16^{\circ} 44^{\prime} 40^{\prime \prime} \mathrm{E}$, xerothermic grassland located on south-facing slope, pitfall traps, leg. et det. T. Rutkowski: 1-15 June $2013-1$ §; 15

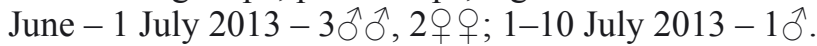

Pierusza [XS 29], $51^{\circ} 25^{\prime} 11^{\prime \prime} \mathrm{N}, 16^{\circ} 45^{\prime} 18^{\prime \prime} \mathrm{E}$, mosaic of small gravel pits and sandy grassland, pitfall traps, leg. et det. T. Rutkowski: 31 May - 15 June $2013-$

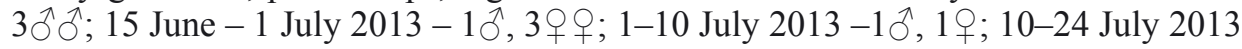
$-2 \hat{\jmath}$.

Poznań-Junikowo [XU 20], 52 23'56”'N, 16 ${ }^{\circ} 56^{\prime} 26^{\prime \prime} \mathrm{E}$, dry anthropogenic grassland, overwintering in empty Helicella obvia shells, leg. et det. T. Rutkowski: 2 Jan $2014-1$ juv.

Poznań-Starołęka [XU 30], 52²2’41'N, 1649'24”E, dry anthropogenic grassland, overwintering in empty Helicella obvia shells, leg. A. Dziabaszewski, T. Rutkowski, det. T. Rutkowski: 29 Dec $2012-5$ subadult $\delta^{\lambda}$.

Santok [WU 24], 52 $44^{\prime} 05^{\prime}$ N, $15^{\circ} 23^{\prime} 19^{\prime}$ 'E, xerothermic grassland (AdonidoBrachypodietum) with Arrhenatherum elatius, pitfall traps, leg. P. Sienkiewicz, det. R. Rozwałka; 16 Apr - 19 May 2013 - 2̧へ̋, 4 juv.; 31 July - 5 Sep 2013 - 1 juv.;

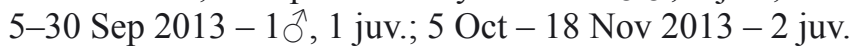

Santok [WU 24], 52 $44^{\prime} 06^{\prime \prime} \mathrm{N}, 15^{\circ} 23^{\prime} 24^{\prime \prime} \mathrm{E}$, xerothermic grassland (AdonioBrachypodietum) with Peucedanum oreoselinum, pitfall traps, leg. P. Sienkiewicz, det. R. Rozwałka: 19 May - 27 June $2013-1 \hat{\jmath}, 1$, 2 juv. 
Smogorzów [XS 19], 51²5’34’N, 16³9’32”E, very wet meadow, pitfall traps, leg. et det. T. Rutkowski: 31 May - 15 June $2013-19,1$ juv.

Smogorzówek [XS 19], 51²5'14”N, 1640'01'E, complex of old gravel pits, sandy grassland, pitfall traps, leg. et det. T. Rutkowski: 31 May -15 June $2013-$ $3 \widehat{\partial} \widehat{o}^{1}, 1$.

Trzcinica Wołowska [XT 20], 51 $26^{\prime} 25^{\prime \prime} \mathrm{N}, 16^{\circ} 44^{\prime} 12^{\prime \prime} \mathrm{E}$, complex of old gravel

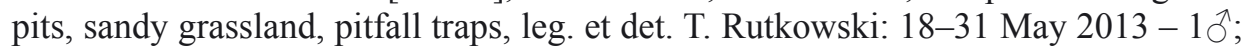
31 May -15 June $2013-1$.

Wińsko [XT 10], 51 $28^{\circ} 12^{\prime \prime} \mathrm{N}, 1^{\circ} 35^{\prime} 30^{\prime \prime} \mathrm{E}$, mosaic of old gravel pits and xerothermic grassland, pitfall traps, leg. et det. T. Rutkowski: 31 May - 15 June 2013

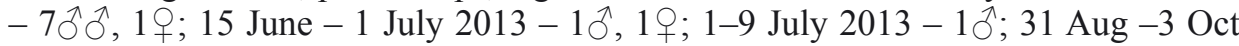
$2013-1$.

Precise descriptions of Talavera aperta can be found in publications of CHVÁTAlovÁ \& Buchar (2002) and Logunov \& Kronestedt (2003). Fig. 1 shows the general appearance of the male body (a) and male palps $(b-c)$ as well as the female epigynum (d).

\section{CONCLUSIONS}

The presented results of field research confirm that Talavera aperta is widespread in western Poland. It is a thermophilous species, preferring various open, sunny habitats, as previously mentioned by BUCHAR \& RŮŽIČKA (2002), CHVÁTALOVÁ \& Buchar (2002), and Logunov \& Kronestedt (2003). Occasional findings of T. aperta in wet habitats (comp. LoGUNOV \& KRONESTEDT 2003) probably concern migrating specimens. Adults of T. aperta were caught mainly in June, although some adults were active most of the summer and autumn (Fig. 3). Overwintering of spiders

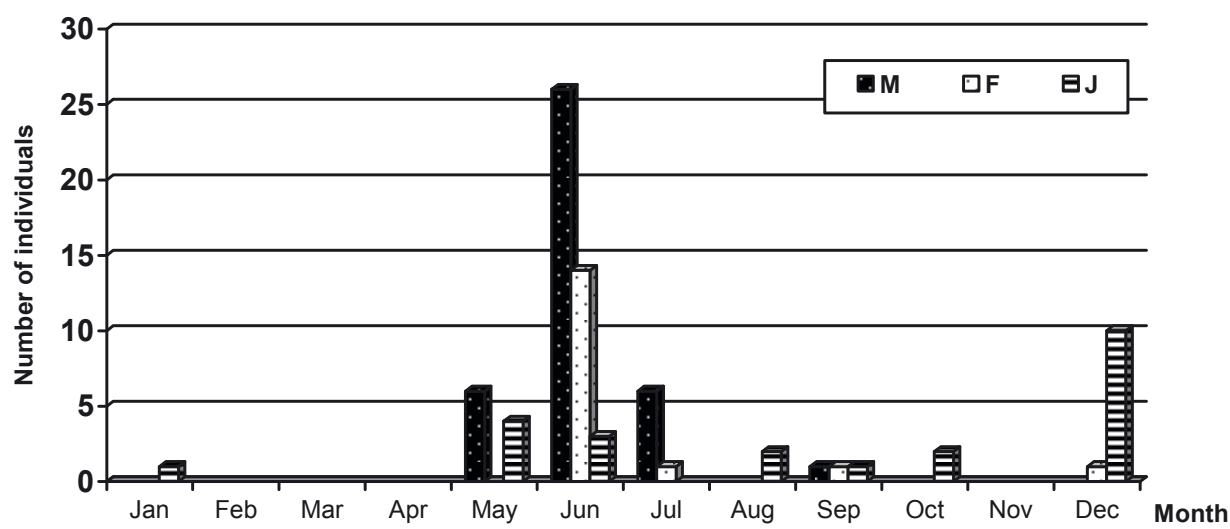

Fig. 3. Seasonal distribution of captured individuals of Talavera aperta, disaggregated by sex and age 
of the genus Talavera in empty shells of land snails is a known phenomenon (HorN 1980; Szinetar et al.1998; Hula et al. 2009; NiedobovÁ et al. 2013). The cited findings concern $T$. aequipes and T. petrensis (C.L. Koch). The only report on T. aperta in snail shells, as a species new to Hungary (SzINETAR et al. 1998), seems to be due to misidentification, as this species is not mentioned in the Hungarian Salticidae checklist (SzÜTs et al. 2003). Therefore it can be assumed that our findings in Poland are the first well-documented cases of affinity of this species to empty land snail shells. Detailed data on overwintering of the spiders in shells in Poland and determination of immature specimens of $T$. aperta will be provided in a separate work.

Acknowledgements: We are very grateful to Prof. Andrzej Dziabaszewski and Dr Grzegorz Wojtaszyn for assistance in some field trips. Special thanks are due to 2 anonymous referees, for their valuable comments that greatly improved the manuscript.

\section{REFERENCES}

AlmQuist S. 2006. Swedish Araneae, part 2 - families Dictynidae to Salticidae. Entomol. Scand. Suppl. 63: 287-603.

Blick T., Bosmans R., Buchar J., Gajdoš P., Hänggi A., van Helsdingen P., Ružicka V., Staręga W., Thaler K. 2004. Checkliste der Spinnen Mitteleuropas (Arachnida: Araneae) [Checklist of the spiders of Central Europe]. Version 1. Dezember 2004: http://www.arages.de/checklist. html\#2004_Araneae (in German).

Buchar J., RǓžIČKA V. 2002. Catalogue of spiders of the Czech Republic. Peres, Praha.

Chvátalová I., Buchar J. 2002. Distribution and habitat of Talavera aperta, T. milleri and T. thorelli in the Czech Republic (Araneae: Salticidae). Acta Soc. Zool. Bohem. 66: 3-11.

Gajdoš P., Svatoñ J., Sloboda K. 1999. Catalogue of Slovakian spiders. Bratislava.

Heimer S., Nentwig W. 1991. Spinnen Mitteleuropas: Ein Bestimmungsbuch. Verlag Paul Parey, Berlin (in German).

HorN H. 1980. Die Bedeutung leerer Schneckengehäusern für Überwinterung und Brutverhalten von Pellenes nigrociliatus L. Koch, 1874 in Steppenrasenformationen (Araneae: Salticidae). Beitr. Naturk. Forsch. Süd- westdeutschl. 39: 167-175 (In German).

Hula V., Niedobová J., Košulič O. 2009. Overwintering of spiders in land-snail shells in South Moravia (Czech Republic). Acta Mus. Morav. Sci. biol. 94: 1-12.

Kupryjanowicz J. 2008. Pająki (Araneae). In: Fauna Polski - charakterystyka i wykaz gatunków (Bogdanowicz W., Chudzicka E., Pilipiuk I,. Skibińska E., Eds), pp. 223-255, MiIZ PAN, Warszawa (in Polish).

Logunov D. V., Kronestedt T. 2003. A review of the genus Talavera Peckham and Peckham, 1909 (Araneae, Salticidae). J. Nat. Hist. 37: 1091-1154.

Miller F. 1971. Pavouci-Araneida. Klíč zvířeny CSS R, Praha, 4: 51-306 (in Czech).

Nentwig W., Hänggi A., Kropf Ch., Blick T. 2016. Spinnen Mitteleuropas - Bestimmungsschlüssel. http://www.araneae.unibe.ch [accessed 8-Feb-2016] (in German).

Niedobová J., Hula V., Košulič O. 2013. Prázdné ulity plžů a tajemství, která skrývají. [Empty Snail Shells and the Secrets they Hide]. Živa 61: 26-28 (in Czech).

Pozzi S., HängGi A. 1998. Araignées nouvelles ou peu connues de la Suisse (Arachnida: Araneae). Mitt. Schweiz. Entomol. Ges. 71: 33-47 (in French).

Prószyński J., StaręGa W. 1997. Araneae. In: Wykaz zwierząt Polski (Razowski J., Ed.), vol. 4, pp. 175-189, Wydawnictwa Instytutu Systematyki i Ewolucji Zwierząt PAN, Kraków (in Polish). 
RozwatKa R. 1995. Pająki zbiorowiska kserotermicznego w Korhyniach koło Tomaszowa Lubelskiego. Streszczenia referatów Polskiego Towarzystwa Zoologicznego Łódź 14-16 IX 1995. Łódź (dodruk): 146 (in Polish).

Staręga W. 1984. Materiały do znajomości rozmieszczenia pająków (Aranei) w Polsce. Fragm. faun. 28: 79-136 (in Polish).

Staudt A. 2016. Nachweiskarten der Spinnen Deutschlands. http://www.spiderling.de/arages [accessed 8-Feb-2016] (in German).

Szinetár Cs., Gál Zs., Eichardt J. 1998. Spiders in snail shells in different Hungarian habitats. Misc. Zool. Hung. 12: 67-75.

SzÜts T., SzinetÁr Cs., SAmu F., Szita É. 2003. Check list of the Hungarian Salticidae with biogeographical notes. Arachnol. Mitt. 25: 45-61 (in German).

van Helsdingen P. 2016. Fauna Europaea: Araneae: Fauna Europaea, version 2.3. http://www.faunaeur.org [accessed 8-Feb-2016]

World Spider Catalog 2016. World Spider Catalog. Natural History Museum Bern. http://wsc. nmbe.ch, version 16 [accessed 8-Feb-2016]

WUNDERLICH J. 2008. On the identification and taxonomy of the central European jumping spiders (Araneae: Salticidae) of the tribus Euophrydini, with special reference to Talavera. Beitr. Araneol. 5: 720-735.

Żabka M. 1997. Salticidae. Pająki skaczące (Arachnida: Araneae) . Fauna Polski, MiIZ PAN Warszawa 19: 1-191 (in Polish).

ŻabKa M., PrószyŃski J. 1998. Middle European Euophrys C. L. Koch, 1834 Salticidae (Araneae: Salticidae) - one, two or three genera? Proceedings of the 17th European Colloquium of Arachnology, Edinburgh 1997: 115-120. 